\title{
Occupational exposure to blood borne pathogens among healthcare workers: a cross-sectional study of a registry in Colombia
}

\author{
Carlos Pérez-Diaz ${ }^{1,2,3}$, Omar-Javier Calixto ${ }^{3^{*}}$, Álvaro A. Faccini-Martínez ${ }^{3,4}$, Juan S. Bravo-Ojeda ${ }^{3}$, \\ Carlos A. Botero-García ${ }^{5}$, Erika Uribe-Pardo ${ }^{3}$, Yesid F. Mantilla-Florez ${ }^{3}$, Fabian Benitez ${ }^{3}$, Ada Duran ${ }^{3}$ \\ and Johana Osorio ${ }^{6}$
}

\begin{abstract}
Background: Occupational exposure to blood borne pathogens caused by percutaneous injuries or mucosal contamination is frequent among Healthcare Workers (HCW).

Methods: A cross-sectional analysis of HCW with an occupational exposure to blood reported to professional risk insurance agencies between 2009 and 2014 was performed. Comparisons between groups according to exposure level (mild, moderate, and severe) were evaluated.

Results: Two thousand, four hundred three reports were classified according exposure as mild $2.7 \%$, moderate $74.8 \%$, severe $21.9 \%$. Factors related: health sciences student with mild exposure events [adjusted odds ratio (AOR) $11.91,95 \% \mathrm{Cl} 5.13-27.61, p<0.00001$ ], and physician with moderate exposure events (AOR 1.90, $95 \% \mathrm{Cl}$ 1.17-3.07, $p=0.009$ ). Factors inversely related: physician with severe exposure events ( $A O R \quad 0.54,95 \% \mathrm{Cl} 0.32-0.91, p=0.02$ ) and health sciences student with moderate exposure events (AOR 0.08, $95 \% \mathrm{Cl} 0.04-0.15, p<0.00001$ ). It was found an important relationship between severe events with infectious diseases specialist assessment, and follow-up adherence. Additionally, a case of Human Immunodeficiency Virus seroconversion was presented (0.0004\%), no other seroconversions were observed.
\end{abstract}

Conclusions: Occupational exposure events must be managed according to established protocols, but adherence failure was evident with the exception of severe exposure cases. Thus, interventions to enhance occupational safety are required. Occupation must be considered as a risk factor during initial assessment of events.

Keywords: Health care worker, Blood borne pathogen, Occupational exposure

\section{Background}

Health Care Workers (HCW) refers to any person that performs a paid or non-paid labor activity in health care $[1,2]$. This population is potentially exposed to infectious materials as corporal fluids and contaminated medical devices and surfaces. HCW include physicians, paramedics, nurses, dentists, technicians, students, and assistants whose role is related directly with health care.

\footnotetext{
* Correspondence: calixto.oj@hotmail.com

${ }^{3}$ Servicios y asesorías en infectología (SAl), Calle 50 \# 13-62, 110231420,

Bogotá, Colombia

Full list of author information is available at the end of the article
}

Additionally the personnel that is indirectly related with patients attention can also be exposed to blood or other fluids, as it is the case of cleaning, security, maintenance and volunteer personnel $[1,2]$.

Biohazard event is defined as the exposure to blood, tissues or any other potentially infectious fluid [1], one of the most obvious occupational risks in $\mathrm{HCW}$ daily practice and produces anxiety among them [3]. Exposure to blood borne pathogens caused by percutaneous injuries or mucous membranes contamination is a frequent event. It is considered, seroconversion risk for blood borne viruses are; $1-6 \%$ to $22-31 \%$ for Hepatitis B 
Virus (HBV) depending on serological status of the source, 1.8 \% for Hepatitis C Virus (HCV), and $0.3 \%$ for the Human Immunodeficiency Virus (HIV) [4]. Worldwide, the cases of infection associated to occupational activity in $\mathrm{HCW}$ represents $39 \%$ of the cases of infection by HCV, $37 \%$ of the cases of infection by HBV, and $4.4 \%$ of the cases of infection by HIV [5]. For the region of the Americas it is considered that 57,000, 61,000 and 23,000 events occur with a positive source to $\mathrm{HCV}, \mathrm{HBV}$ and HIV, respectively [5].

Universal precaution recommendations have been created for prevention, especially needles and sharp objects injuries, as well as preventing contact of fluids with mucous membranes [6].

In Colombia once the exposure event occurs the HCW must contact their insurance agency in order to be advice of initial treatment and risk assessment in the emergency room or presenting to a specialized consultation service. But there is not an integrated national record of these events, for that reason the objective of this study is to analyze the reports of exposure to blood and corporal fluids of five professional risk insurance companies in Colombia between years 2009 and 2014, as well as determining the factors associated to mild, moderate, and severe exposure classification.

\section{Methods}

\section{Study design}

The study was an epidemiological, retrospective, record-based review. This study included registries of Colombian HCWs who presented an episode of exposure to blood borne pathogens caused by percutaneous injuries or mucous membranes contamination reported to five professional risks insurance companies and evaluated in Servicios y Asesorías en Infectología (SAI), which performed the occupational exposure initial management and follow-up, between years 2009 and 2014. The present study protocol was approved by the Institutional Review Board, SAI.

The sample size was calculated taking into account the formula for this type of study based on expected prevalence of occupational exposure events in a local teaching hospital from Colombia (31.6 \%) [31]. Based on an alpha risk of $5 \%$ with a confidence level of $99 \%$ and a twosided configuration. As a result, the estimated sample size was 2294 subjects.

Needle puncture or sharp object injuries and cutaneous or mucosal splashes were surveyed by reports of exposures assessed in a specialized infectious diseases agency. The follow up consisted in guaranteeing and guiding the medical advice, and treatment of cases according to their classification in mild, moderate or severe exposure events. Sociodemographic, clinical and laboratory data were obtained from the event registries and double-check with medical registries by two investigators in order to control bias. These data was registered in an electronic database.

\section{Statistical analysis}

In the first place, a univariate descriptive analysis was performed. Categorical variables were analyzed through frequencies. The Kolmogorov-Smirnov test was performed to evaluate the normality. Parametric data is expressed with the mean and standard deviation (SD), and non-parametric data is described with median and interquartile range (IQR).

Subsequently, a bivariate analysis was performed to establish association between demographic and clinical characteristics of the patients. Parametric values were analyzed by chi-square test or Fisher exact test. A value of $p \leq 0.05$ was considered as significant.

A multiple logistic regression was considered by taking the exposure level classification as independent variables. As dependent factors: statistically significant associations in the bivariate analysis were used, as additional variables described in the literature.

The adequacy of the logistic models was evaluated through Hosmer-Lemeshow goodness-of-fit test. The Nagelkerke R2 was used to estimate the percentage of variance explained by the model. The adjusted odds ratio (AOR) was calculated with confidence intervals of $95 \%(\mathrm{CI})$. Wald statistic test was used to evaluate the significance of different logistic regression coefficients for each independent variable. A step by step progressive elimination approach was used. Statistical analyses were made in the statistical program IBM SPSS Statistics 22.

\section{Results}

Characteristics of the 2403 participants, $82.4 \%$ were females, with a mean age between $29.5 \pm 9.2$ years. Regarding their origin, 69.8 \% came from urban areas, the remaining percentage of cases occurred in rural areas. Biohazard events were classified as mild in $2.7 \%$, moderate in $74.8 \%$ and severe in $21.9 \%$. The main mechanisms were: needle puncture (hollow needle, blunt needle, or unspecified needle) $86.5 \%$, mucocutaneous splash $7.9 \%$, and injuries with contaminated sharp object $5.6 \%$. For further description of demographical data and injury mechanisms, see Table 1.

During follow up, it was found that $21.5 \%$ received any type of prophylaxis for the HIV infection. However, prophylaxis in severe exposures was received in $94.6 \%$ cases. The most used drug was zidovudine/lamivudine (AZT/3TC) in $87.1 \%$, followed by AZT/3TC plus lopinavir/ritonavir in $8.8 \%$ and emtricitabine/tenofovir in 
Table 1 Characteristics of the health care workers with occupational exposure

\begin{tabular}{|c|c|c|}
\hline Sociodemographic characteristics & Mean \pm SD & Median, IQR \\
\hline \multirow[t]{2}{*}{ Age (y) } & $29.5 \pm 9.2$ & \multirow[t]{2}{*}{$27,28.8-48.3$} \\
\hline & $\%(n / N)$ & \\
\hline Female & \multicolumn{2}{|l|}{$82.4(1980 / 2403)$} \\
\hline Urban area & \multicolumn{2}{|l|}{$69.8(1677 / 2402)$} \\
\hline Occupation & \multicolumn{2}{|l|}{$\%(n / N)$} \\
\hline Nursing & \multicolumn{2}{|l|}{$47.5(1141 / 2403)$} \\
\hline Physician & \multicolumn{2}{|l|}{$13.9(334 / 2403)$} \\
\hline Student & \multicolumn{2}{|l|}{$13.1(315 / 2403)$} \\
\hline Cleaning personnel & \multicolumn{2}{|l|}{$9.6(230 / 2403)$} \\
\hline Odontology & \multicolumn{2}{|l|}{$7.3(175 / 2403)$} \\
\hline Bacteriology & \multicolumn{2}{|l|}{$4.9(118 / 2403)$} \\
\hline Surgical instrumentation & \multicolumn{2}{|l|}{$2.6(62 / 2403)$} \\
\hline Respiratory therapy & \multicolumn{2}{|l|}{$1.1(27 / 2403)$} \\
\hline Contact Mechanism & \multicolumn{2}{|l|}{$\%(n / N)$} \\
\hline Hollow needle & \multicolumn{2}{|l|}{$53.0(1272 / 2403)$} \\
\hline Unspecified needle & \multicolumn{2}{|l|}{$22.8(548 / 2403)$} \\
\hline Blunt needle & \multicolumn{2}{|l|}{$10.7(256 / 2403)$} \\
\hline Mucocutaneous splash & \multicolumn{2}{|l|}{$7.9(190 / 2403)$} \\
\hline Lancet puncture & \multicolumn{2}{|l|}{$4.1(99 / 2403)$} \\
\hline Scalpel injury & \multicolumn{2}{|l|}{$1.3(31 / 2403)$} \\
\hline Contaminated glass injury & \multicolumn{2}{|l|}{$0.2(5 / 2403)$} \\
\hline Exposure Classification & \multicolumn{2}{|l|}{$\%(n / N)$} \\
\hline Mild & \multicolumn{2}{|l|}{$2.7(67 / 2403)$} \\
\hline Moderate & \multicolumn{2}{|l|}{$74.8(1798 / 2403)$} \\
\hline Severe & \multicolumn{2}{|l|}{$21.9(527 / 2403)$} \\
\hline Follow up & \multicolumn{2}{|l|}{$\%(n / N)$} \\
\hline Medical follow-up & \multicolumn{2}{|l|}{$33.1(796 / 2403)$} \\
\hline Infectious diseases specialist assessment & \multicolumn{2}{|l|}{$30.3(728 / 2403)$} \\
\hline Prophylactic medication & \multicolumn{2}{|l|}{$21.5(517 / 2403)$} \\
\hline
\end{tabular}

$I Q R$ interquartile range, $S D$ standard deviation, $y$ years

$2 \%$. Other included medication regimens used were abacavir/lamivudine, atazanavir, efavirenz, and raltegravir. And 7 (0.3\%) patients received human immunoglobulin due to exposition to HBV.

Additionally, $30.3 \%$ of the cases reported assessment by infectious diseases specialist, and $33.1 \%$ had a medical follow-up 6 months after the event. However, in patients classified as severe exposure, 99.2 and $68.9 \%$ were assessed by infectious diseases specialist and received medical follow-up, respectively. A case of seroconversion to HIV was presented during the study time period, representing $0.0004 \%$ of all the followed cases. Furthermore, there was no other disease transmission diagnosed during the follow up time.

\section{Factors associated to the type of exposure}

In bivariate analysis, mild exposure was significantly related to health sciences students $(p=<0.00001)$. In contrast, being a nurse $(p=0.015)$, assessment by an infectious diseases specialist $(p=0.025)$, and presenting a medical follow-up during follow up $(p=<0.00001)$ were associated inversely with mild exposure (Table 2 ).

Factors significantly related to moderate exposure events were physicians $(p=<0.00001)$, and respiratory therapists $(p=0.041)$; however, the confidence interval of the group of respiratory therapy included the unit (CI95\% 0.98-17.58). Meanwhile health sciences student $(p=0.048)$, and cleaning personnel $(p=<0.00001)$, infectious diseases specialist assessment $(p=<0.00001)$, and medical follow-up $(p=<0.00001)$ were inversely related (Table 2).

Factors related severe exposure events were cleaning personnel $(p=<0.00001)$, as well as infectious diseases specialist assessment $(p=<0.00001)$, receiving post-exposure prophylaxis $(p=<0.00001)$, and medical follow-up $(p=<0.00001)$. Contrary, there was an inverse relationship between being a physician $(p=0.001)$ (Table 2$)$.

As a result of a multivariate analysis it was found in mild exposure events, being a health sciences student was related to presenting a mild exposure event (AOR 11.91, $95 \%$ CI 5.13-27.61, $p=<0.00001$ ). In contravention, having a medical follow-up was inversely related (AOR 0.19, 95 \% CI 0.05-0.64, $p=0.008$ ) (Table 3).

Moderate exposure, in multivariate analysis was associated with being a physician (AOR 1.90, 95 \% CI 1.173.07, $p=0.009$ ). While, health sciences students was inversely related to moderate exposure events (AOR 0.08 , $95 \%$ CI 0.04-0.15, $p=<0.00001)$. Also, infectious diseases specialist assessment (AOR 0.01, 95 \% CI 0.01$0.15, p=<0.00001$ ), and medical follow-up (AOR 0.67, $95 \%$ CI 0.47-0.94, $p=0.020$ ), (Table 3).

Severe exposure in multivariate analysis showed relationship with infectious diseases specialist assessment (AOR 1160.89, 95 \% CI 285.56-4719.37, $p=<0.00001$ ), and the medical follow-up (AOR 1.83, $95 \%$ CI 1.28$2.63, p=0.001$ ). Although, physicians were inversely related to this classification (AOR 0.54, $95 \%$ CI 0.32-0.91, $p=0.021)$ (Table 3).

\section{Discussion}

One of the most related factors to biohazard events in $\mathrm{HCW}$ is occupation; previously, different studies have reported that exposure to blood borne pathogens is more frequent in personnel that must manipulate vascular accesses or blood samples such as nursing personnel (nurses and nursing assistants), physicians, and laboratory personnel [7-20].

According to these findings in our registry it was clear that the most frequently related occupations were: 
Table 2 Bivariate analysis of event according to exposure classification

\begin{tabular}{|c|c|c|c|c|}
\hline Mild exposure & Yes \% & No $\%$ & OR (Cl $95 \%)$ & $p$ value \\
\hline Female & 76.6 & 82.6 & $0.69(0.35-1.37)$ & 0.287 \\
\hline Urban area & 80.6 & 69.5 & $1.82(0.99-3.36)$ & 0.051 \\
\hline Physician & 6.0 & 14.1 & $0.39(0.14-1.07)$ & 0.071 \\
\hline Student & 34.3 & 12.5 & $3.66(2.18-6.15)$ & $<0.00001$ \\
\hline Nursing & 32.8 & 47.9 & $0.53(0.32-0.89)$ & 0.015 \\
\hline Bacteriology & 4.5 & 4.9 & $0.91(0.28-2.92)$ & 1.000 \\
\hline Odontology & 7.5 & 7.3 & $1.03(0.41-2.56)$ & 0.814 \\
\hline Surgical Instrumentation & 6.0 & 2.5 & $2.49(0.88-7.08)$ & 0.092 \\
\hline Cleaning personnel & 9.0 & 9.6 & $0.93(0.40-2.17)$ & 0.861 \\
\hline Respiratory therapy & 0.0 & 1.2 & $1.03(1.02-1.04)$ & 1.000 \\
\hline Infectious diseases specialist assessment & 17.9 & 30.7 & $0.49(0.26-0.93)$ & 0.025 \\
\hline Prophylactic medication & 0.0 & 22.1 & $1.04(1.03-1.05)$ & $<0.00001$ \\
\hline Medical follow-up & 11.9 & 33.9 & $0.26(013-0.56)$ & $<0.00001$ \\
\hline Moderate exposure & Yes \% & No $\%$ & OR (Cl $95 \%)$ & $p$ value \\
\hline Female & 82.7 & 81.4 & $1.90(0.83-1.43)$ & 0.525 \\
\hline Urban area & 70.1 & 69.0 & $1.05(0.86-1.29)$ & 0.627 \\
\hline Physician & 15.5 & 8.9 & $1.88(1.38-2.56)$ & $<0.00001$ \\
\hline Student & 12.3 & 15.5 & $0.77(0.59-0.99)$ & 0.048 \\
\hline Nursing & 48.6 & 44.1 & $1.20(0.99-1.45)$ & 0.056 \\
\hline Bacteriology & 4.9 & 4.9 & $1.01(0.66-1.55)$ & 0.968 \\
\hline Odontology & 7.0 & 8.2 & $0.83(0.59-1.18)$ & 0.298 \\
\hline Surgical Instrumentation & 2.8 & 2.0 & $1.38(0.73-2.61)$ & 0.320 \\
\hline Cleaning personnel & 7.5 & 16.0 & $0.42(0.32-0.56)$ & $<0.00001$ \\
\hline Respiratory therapy & 1.4 & 0.3 & $4.15(0.98-17.58)$ & 0.041 \\
\hline Infectious diseases specialist assessment & 10.7 & 90.1 & $0.13(0.01-0.02)$ & $<0.00001$ \\
\hline Prophylactic medication & 0.0 & 87.0 & $24.48(19.67-30.47)$ & $<0.00001$ \\
\hline Medical follow-up & 23.7 & 62.5 & $0.19(0.15-0.23)$ & $<0.00001$ \\
\hline Severe exposure & Yes \% & No $\%$ & OR (Cl $95 \%)$ & $p$ value \\
\hline Female & 82.0 & 82.5 & $0.96(0.73-1.28)$ & 0.068 \\
\hline Urban area & 67.6 & 70.5 & $0.87(0.71-1.08)$ & 0.200 \\
\hline Physician & 9.3 & 15.2 & $0.57(0.42-0.79)$ & 0.001 \\
\hline Student & 13.1 & 13.1 & $0.99(0.75-1.33)$ & 0.987 \\
\hline Nursing & 45.5 & 48.1 & $0.90(0.75-1.10)$ & 0.308 \\
\hline Bacteriology & 4.9 & 4.9 & $1.01(0.64-1.57)$ & 0.980 \\
\hline Odontology & 8.3 & 7.0 & $1.21(0.85-1.73)$ & 0.288 \\
\hline Surgical Instrumentation & 1.5 & 2.9 & $0.52(2.46-1.10)$ & 0.082 \\
\hline Cleaning personnel & 16.9 & 7.5 & $2.50(1.88-3.32)$ & $<0.00001$ \\
\hline Respiratory therapy & 0.4 & 1.3 & $0.28(0.07-1.19)$ & 0.097 \\
\hline Infectious diseases specialist assessment & 99.2 & 10.9 & $1065.13(394.06-2879.05)$ & $<0.00001$ \\
\hline Prophylactic medication & 98.1 & 0.0 & $188.50(101.59-349.76)$ & $<0.00001$ \\
\hline Medical follow-up & 68.9 & 23.3 & $7.28(5.89-9.02)$ & $<0.00001$ \\
\hline
\end{tabular}


Table 3 Multiple logistic regression of event according to exposure classification

\begin{tabular}{|c|c|c|c|c|}
\hline \multicolumn{5}{|l|}{ Mild classification logistic regression model } \\
\hline Variable & $\beta$ & $A O R$ & Cl $95 \%$ & $p$ value \\
\hline Constant & -3.397 & 0.020 & - & $<0.0000001$ \\
\hline Gender (female) & -0.234 & 0.792 & $0.381-1.647$ & 0.532 \\
\hline Student & 2.477 & 11.901 & $5.129-27.613$ & $<0.0000001$ \\
\hline Nursing & 0.388 & 1.475 & $0.624-3.487$ & 0.376 \\
\hline Infectious diseases specialist assessment & -0.065 & 0.937 & $0.411-2.134$ & 0.877 \\
\hline Medical control & -1.684 & 0.186 & $0.054-0.642$ & 0.008 \\
\hline \multicolumn{5}{|c|}{ Moderate classification logistic regression model } \\
\hline Variable & $\beta$ & $\mathrm{AOR}$ & $\mathrm{Cl} 95 \%$ & $p$ value \\
\hline Constant & 3.845 & 46.750 & - & $<0.0000001$ \\
\hline Gender (female) & 0.347 & 1.414 & $0.924-2.164$ & 0.110 \\
\hline Physician & 0.641 & 1.898 & $1.174-3.068$ & 0.009 \\
\hline Student & -2.532 & 0.080 & $0.042-0.149$ & $<0.0000001$ \\
\hline Respiratory therapy & 0.251 & 1.286 & $0.184-8.984$ & 0.800 \\
\hline Infectious diseases specialist assessment & -4.708 & 0.009 & $0.006-0.15$ & $<0.0000001$ \\
\hline Medical follow-up & -0.406 & 0.667 & $0.473-0.939$ & 0.020 \\
\hline \multicolumn{5}{|c|}{ Severe classification logistic regression model } \\
\hline Variable & $\beta$ & $\mathrm{AOR}$ & Cl $95 \%$ & $p$ value \\
\hline Constant & -6.328 & 0.002 & - & $<0.0000001$ \\
\hline Gender (female) & -0.362 & 0.697 & $0.416-1.166$ & 0.169 \\
\hline Physician & -0.613 & 0.542 & $0.322-0.911$ & 0.021 \\
\hline Cleaning personnel & 0.173 & 1.189 & $0.662-2.135$ & 0.563 \\
\hline Infectious diseases specialist assessment & 7.057 & 1160.887 & $285.559-4719.372$ & $<0.0000001$ \\
\hline Medical follow-up & 0.604 & 1.830 & $1.275-2.626$ & 0.001 \\
\hline
\end{tabular}

AOR Adjusted Odds Ratio, $\mathrm{Cl}$ confidence interval

nursing, physician and health sciences student. Nursing with $47.5 \%$ (1141 registries), although this value is not as high as reported in Spain (61.6-78 \%) [17], Poland (68 \%) [12], and Egypt (66.7 \%) [11]. However, a similar percentage is found in other countries as Turkey (44\%) [7], and Georgia (39\%) [9]. This variation may be due to the current record includes professions not considered by these studies as students, cleaning personnel, laboratory personnel, and not only physicians and/or nurses.

To our knowledge there are few studies that have attempted to perform an analysis according to the severity classification proposed by the CDC, in our study statistically significant associations were found with each category; it was found and association to mild exposure event and being a student, that could be related to the population that presented more events with blunt needle $(46.3 \%)$ and mucosal splash $(22.4 \%)$ that is generally associated to mild exposure.

Physicians were associated to moderate severity exposure events, possibly explained by main exposure mechanisms as blunt needle puncture $(32.1 \%)$ and hollow needle puncture $(30.2 \%)$ in this occupational group.

Contrariwise being a physician was inversely associated to severe exposure events since physicians only represented $9.2 \%$ of the cases. An interesting finding was that despite it was not evident an association in the logistic regression model, being part of the cleaning personnel was associated to severe exposure events, were $96.6 \%$ of the reported events were associated to hollow needle puncture or unspecified needle puncture with unknown source.

A study including different occupational groups by Montufar-Andrade F, et al. [20]. conducted in Colombia, informed the occupational exposure in nursing (22.9\%), cleaning personnel $(21.7 \%)$, students in formation in $14.3 \%$, and physicians in $4.2 \%$, similarly to those found in our study. Additionally, In Turkey there was reported a $34 \%$ of cleaning personnel in the exposure registries [7]. Regarding severe classification group, in Tunisia it 
was found that being part of the nursing personnel was a risk factor [14], and Colombian medical students in practice during surgical areas was associated to severe events [21].

Among factors reported previously associated to exposure to biological material in $\mathrm{HCW}$ are: working in the emergency room, working in the operating room, working in the ICU or in resuscitation area, inadequate illumination system, age under 25 years, lack of experience, workload $>40$ hours/week, lack of training in infection risk, and inconsistency in the use of gloves [16, 22-25]. Even, in some cases the use of gloves was only present in $47 \%$ of the events [26]. Additionally, there was an association in HCW as students in formation, especially during surgical practices [21, 27-31], gynecology and obstetrics [21, 27-32], anesthesiology [31], internal medicine [27], or in the emergency room [29]. Those who were in surgical areas had the presence of severe exposure events [21], and nearly $20 \%$ did not register the use of protective materials [28]. In the United Kingdom it was found that most physicians experienced events with suture (blunt) needles, while younger physicians presented exposure during laboratory sample recollection [33].

During the protocol period a case of HIV seroconversion occurred $(0.0004 \%)$; this case was recently described as the first case HIV seroconversion in a $\mathrm{HCW}$ from Colombia; the event occurred in 2005 and the patient did not receive post expositional prophylaxis [34], making clear the importance of a protocol for the proper and prompt attention of these events. On the other hand, no other additional infections were recorded in $\mathrm{HCW}$.

Adherence is a major concern in HCW occupational exposure protocols with a large percentage of professionals that do not complete the prophylactic recommendations or fail to attend to follow-up and evaluation by an infectious diseases specialist [35, 36]; in an analysis of all the reports it was noticed that only $21.5 \%$ received any type of post expositional prophylaxis with antiretroviral medication, $33.1 \%$ assisted to medical followup, and $30.3 \%$ assisted to an appointment with infectious diseases specialist. However it is noteworthy that those patients classified as severe exposure $94.6 \%$ received post expositional prophylaxis, $99.2 \%$ assisted to medical control and $68.9 \%$ were evaluated by an infectious diseases specialist.

Factors associated with poor adherence to protocol in $\mathrm{HCW}$ are described as poor risk awareness or lack of time, and these arguments could lead to an important sub-registry $[4,19]$. In Colombia a study conducted by Tapias-Vargas LE et al. [29] in a group of residents, it was found that $31 \%$ of this $\mathrm{HCW}$ did not report the event, and therefore did not received any guidance or comprehensive assessment.
There are several limitations of the current study consists in the retrospective character of the data and absence of sampling methodology. Similarly, other factors previously reported abroad could not be analyzed based on registries used. Although reports from several regions of the country where analyzed, including urban and rural areas, we cannot ensure representativeness of all the $\mathrm{HCW}$ population nationwide and underreport could be also considered since $\mathrm{HCW}$ must contact initially agencies in order to access to the program. Additionally, the transversal nature of the study does not allow making an inference of causality of the associated factors presented.

\section{Conclusion}

Occupational exposure events must be managed according to established protocols, but adherence failure was evident with the exception of severe exposure cases in this study and generally on published literature, so these results can promote the study of determinants in lack of adherence in Colombian HCWs. This study added evidence of relevance in the initial management of occupation, thus allowed a more specific assessment in HCWs with severe exposure classification.

\section{Abbreviations}

AOR: adjusted odds ratio; Cl: confidence intervals; HCW: healthcare workers; HBV: Hepatitis B Virus; HCV: Hepatitis C Virus; HIV: Human Immunodeficiency Virus; IQR: interquartile range; 3TC: lamivudine; SD: standard deviation; AZT: zidovudine.

\section{Competing interests}

All authors report no conflicts of interest relevant to this article.

\section{Authors' contributions}

OJC, AFM, JSBO, and CABG participated in the design of the study and drafting of the manuscript. AE, YFMF, FB, and AD carried out the review of participant's registries and database development. OJC and AFM review the database information. OJC carried out the statistical analysis. CMP and CPD drafted the design of study, and supervised the study implementation. All authors read and approved the final manuscript.

\section{Acknowledgments}

We thank Servicios y asesorías en infectología (SAI) for data provided.

\section{Author details}

${ }^{1}$ Infectious Diseases Department, Clinica Marly, Bogotá, Colombia. ${ }^{2}$ Infectious Diseases Department, Hospital de la Samaritana, Bogotá, Colombia. ${ }^{3}$ Servicios y asesorías en infectología (SAI), Calle 50 \# 13-62, 110231420, Bogotá,

Colombia. ${ }^{4}$ School of Medicine, Universidad de la Sabana, Chia, Colombia.

${ }^{5}$ School of Medicine, Universidad Militar Nueva Granada, Bogotá, Colombia.

${ }^{6}$ School of Medicine, Fundación Universitaria Navarra, Neiva, Colombia.

Received: 12 June 2015 Accepted: 11 December 2015

Published online: 16 December 2015

\section{References}

1. Kuhar DT, Henderson DK, Struble KA, Heneine W, Thomas V, Cheever LW, et al. Updated US Public Health Service guidelines for the management of occupational exposures to human immunodeficiency virus and recommendations for postexposure prophylaxis. Infect Control Hosp Epidemiol. 2013;34:875-92. 
2. Panlilio A, Cardo D, Grohskopf L, Heneine W, Ross C. Guidelines for the management of occupational exposures to HIV and recommendations for postexposure prophylaxis. MMWR. 2005;54:1-17.

3. Wald J. The psychological consequences of occupational blood and body fluid exposure injuries. Disabil Rehabil. 2009;31:1963-9.

4. CDC. Updated US public health service guidelines for the management of occupational exposure to HBV, HCV, and HIV and recommendations for PEP. MMWR Recomm Rep. 2001;50(RR-11):1-52.

5. Prüss-Üstün A, Rapiti E, Hutin Y. Estimation of the global burden of disease attributable to contaminated sharps injuries among health-care workers. Am J Ind Med. 2005;48:482-90.

6. Hamlyn E, Easterbrook P. Occupational exposure to HIV and the use of postexposure prophylaxis. Occup Med (Chic III). 2007:57:329-36.

7. Gönen I. Percutaneous injuries among healthcare workers at a general hospital. J Microbiol Infect Dis. 2011;1:26-30.

8. Gumodoka B, Favot I, Berege ZA, Dolmans WM. Occupational exposure to the risk of HIV infection among health care workers in Mwanza Region, United Republic of Tanzania. Bull. Bull World Health Organization. 1997;75:133-40.

9. Butsashvili M, Kamkamidze G, Kajaia M, Morse DL, Triner W, Dehovitz J, et al. Occupational exposure to body fluids among health care workers in Georgia. Occup Med (Lond). 2012;62:620-6.

10. Kosgeroglu N, Ayranci U, Vardareli E, Dincer S. Occupational exposure to hepatitis infection among Turkish nurses: frequency of needle exposure, sharps injuries and vaccination. Epidemiol Infect. 2004;132:27-33.

11. Omar AA, Abdo M, Salama F, Al-mousa HH. Occupational Injuries Prone to Infectious Risks amongst Healthcare Personnel in Kuwait: A Retrospective Study. Med Princ Pract 2014; :1-6.

12. Różańska A, Szczypta A, Baran M, Synowiec E, Bulanda M, Wałaszek M. Healthcare workers' occupational exposure to bloodborne pathogens: a 5-year observation in selected hospitals of the Małopolska province. Int J Occup Med enviromental Heal. 2014;27:747-56.

13. Liu XN, Sun $X Y$, van Genugten L, Shi YH, Wang YL, Niu WY, et al. Occupational exposure to blood and compliance with standard precautions among health care workers in Beijing, China. Am J Infect Control. 2014;42 e37-8.

14. Hajjaji Darouiche M, Chaabouni T, Jmal Hammami K, Messadi Akrout F, Abdennadher M, Hammami A, et al. Occupational blood exposure among health care personnel and hospital trainees. Int J Occup Environ Med. 2014; 5:57-61.

15. Helena Palucci Marziale M, Ludmilla Rossi Rocha F, Lúcia do Carmo Cruz Robazzi M, Maria Cenzi C, Ehmke Cardoso dos Santos H, Elisa Mendes Trovó M. Organizational influence on the occurrence of work accidents involving exposure to biological material. Rev Lat Am Enfermagem. 2013;21:199-206.

16. Leiss JK. Work experience, work environment, and blood exposure among home care and hospice nurses. Ind Health. 2012;50(6):521-8.

17. Blázquez RM, Moreno S, Menasalvas A, Guerrero C, Novoa A, Segovia M. Exposición a patógenos hemáticos en el personal sanitario. Enferm Infecc Microbiol Clin. 2001;19:156-60.

18. Hernández Navarrete MJ, Montes Villameriel FJ, Solano Bernad VM, Sánchez Matienzo D, del Val García JL, Gil Montalbán E, et al. Accidentes con material biológico en trabajadores sanitarios de 2 áreas de atención primaria (1990-1999). Aten Primaria. 2001;28:255-8.

19. Panunzio A, Nuñez-Barboza M, Molero-Zambrano T, Sirit Y, Zambrano M, Fuentes $B$, et al. Accidentalidad por fluidos biológicos en profesionales de laboratorios clínicos de Maracaibo, Venezuela. Rev Salud Pública. 2010;12: 93-102.

20. Montufar Andrade FE, Madrid Muñoz CA, Villa Franco JP, Diaz Correa LM, Vega Miranda J, Vélez Rivera JD, Accidentes ocupacionales de riesgo biológico en Antioquia, Colombia. Enero de 2010 a diciembre de 2011. Infectio 2014; 18(3):79-85.

21. Martínez Díaz LA, Cadena Afanador LP. Los accidentes biológicos entre estudiantes de medicina: el caso de la UNAB. Med UNAB. 2001:4:161-6.

22. Moon CS, Hwang JH, Lee CS, Park KH, Kim ES. Exposure to blood and body fluid among medical students in Korea. Am J Infect Control. 2010;38:582-3.

23. Yenesew MA, Fekadu GA. Occupational exposure to blood and body fluids among health care professionals in Bahir Dar town, Northwest Ethiopia. Saf Health Work. 2014;5:17-22

24. Campins M, Torres M, Varela P, López Clemente V, Gascó A, de la Prada M, et al. Accidentes biológicos percutáneos en el personal sanitario: análisis de factores de riesgo no prevenibles mediante precauciones estándares. Med Clin (Barc). 2009;132:251-8.

25. Tesfay FA, Habtewold TD. Assessment of prevalence and determinants of occupational exposure to HIV infection among healthcare workers in selected health institutions in debre Berhan town, North shoa zone, Amhara region, Ethiopia, 2014. AIDS Res Treat. 2014;2014:731848.

26. Zhang M, Wang H, Miao J, Du X, Li T, Wu Z. Occupational exposure to blood and body fluids among health care workers in a general hospital, China. Am J Ind Med. 2009;52:89-98.

27. Osborn EH, Papadakis MA, Gerberding JL. Occupational exposures to body fluids among medical students. A seven-year longitudinal study. Ann Intern Med. 1999;130:45-51.

28. Alberth Cristian HG, Ossa RG. Accidentes por riesgos biológicos en los estudiantes de medicina y médicos internos de la Universidad Tecnológica de Pereira. Rev Médica Risaralda. 2003:9:1-10.

29. Tapias-vargas LF, Torres SA, Tapias Vargas L, Santamaria CM, Valencia Angel $\mathrm{LI}$, Orozco Vargas LI. Accidentes biológicos en médicos residentes de Bucaramanga, Colombia. Rev Colomb Cir. 2010;25:290-99.

30. Eduardo Lozano C, Gissella González A, Del Pilar Cadena L. Caracterización de los accidentes por exposición a agente biológico en una población de estudiantes de medicina de Bucaramanga. Infectio. 2012;16:204-10.

31. Davanzo E, Frasson C, Morandin M, Trevisan A. Occupational blood and body fluid exposure of university health care workers. Am J Infect Control. 2008;36:753-6.

32. Fica CA, Jemenao PMI, Ruiz RG, Larrondo M, Hurtado C, Muñoz G, et al. Accidentes de riesgo biológico entre estudiantes de carreras de la salud: Cinco años de experiencia. Rev Chil infectología. 2010;27:34-9.

33. Naghavi SHR, Sanati KA. Accidental blood and body fluid exposure among doctors. Occup Med (Chic III). 2009;59:101-6.

34. Montufar FE, Villa JP, Vélez JD, Zuleta JJ. Investigación de infección por VIH posterior a exposición ocupacional de riesgo biológico en trabajadores de la salud. Infectio. 2014;19:31-4.

35. Shokuhi S, Gachkar L, Alavi-Darazam I, Yuhanaee P, Sajadi M. Occupational exposure to blood and body fluids among health care workers in teaching hospitals in Tehran, Iran. Iran Red Crescent Med J. 2012;14:402-7.

36. Martins AMEDBL, Pereira RD, Ferreira RC. Compliance with occupational post-exposure protocol for injuries among dental surgeons. Rev Saude Publica. 2010;44:528-40

\section{Submit your next manuscript to BioMed Central and we will help you at every step:}

- We accept pre-submission inquiries

- Our selector tool helps you to find the most relevant journal

- We provide round the clock customer support

- Convenient online submission

- Thorough peer review

- Inclusion in PubMed and all major indexing services

- Maximum visibility for your research

Submit your manuscript at www.biomedcentral.com/submit
C Biomed Central 